\title{
Research on Financing Predicament and Breakthrough Countermeasures of China's Affordable Housing
}

\author{
Chunjiao Liu \\ Wuhan University of Technology \\ Wuhan, China \\ walcjngu@163.com
}

\begin{abstract}
Promoting the construction of affordable housing is a key livelihood project for the state to ensure the well-being of people, safeguard social fairness and justice. However, because of the shortage of funds, the coverage and construction progress of this project are far from the expected targets. Hence, the paper firstly summarizes three specific manifestations of China's affordable housing financing difficulties: excessive reliance on government financial support, low social capital investment and high financing risk; and then proposes four breakthrough countermeasures, namely, improve the role and function of government, actively explore financing modes, enrich the return of funds and prefect risk guarantee mechanism, with a view to partially solving the financing problem of affordable housing and promoting the sustained and healthy development of affordable housing .
\end{abstract}

Keywords-affordable housing; financing predicament; financing model; social capital

\section{INTRODUCTION}

In recent years, China's real estate market has developed rapidly and housing prices remain high. It is difficult for the low and middle income families in cities and towns to afford the high housing prices, which leads to the increasingly serious housing problem. In order to solve the housing problem of the middle and low income families, China has vigorously developed affordable housing construction. In the "12th FiveYear" period, China planned to build 36 million new affordable housing. In 2017, it plans 6 million sets of shantytowns, and strives to basically complete the existing shantytowns, villages and dilapidated buildings in 2020. In the process of large-scale construction of affordable housing in China, the demand for funds is increasing. Owing to the welfare and public welfare of affordable housing, the financing of affordable housing is rather difficult, and relying solely on government funding is far from enough to meet demand. Therefore, the shortage of funds has become a key problem that restricts the development of affordable housing. Therefore, we need to make specific analysis of the problems in the financing of the affordable housing to find out solutions, which is of great significance for breaking the funding bottleneck of affordable housing.

\section{THE SUMmARY OF THE RESEARCH ON THE FINANCING OF AFFORDABLE HOUSING}

The developed countries have developed affordable housing early, and the researches on the financing of the housing are more thorough. The main research direction is government investment to market oriented investment in the affordable housing financing mode, formed many innovative mode, including real estate investment trusts (REITs), publicprivate partnership (PPP), asset-backed securitization (ABS), equity financing, etc. Gordon H.Sellon (1998), Noah Kofi Karley (2002), John Erickson (2004) studied the operation mechanism of REITs, indicating that individuals and institutions can invest in real estate through REITs. Martha Minnow (2003) believed that the government and enterprises can cooperate to achieve win-win and multi-win situation in the construction of affordable housing. Lawson and Milligan (2007) pointed out that the government is the facilitator of the construction of affordable housing, not the executor, and the government should attract social investment by making preferential policies and other measures [1]. V.Milligan and T.Gilmour (2012) put forward the construction strategy of affordable housing under the PPP mode [2]. Dzuljastri Abdul Razak and Mustafa Mohammed (2015) studied the application of BOT mode in affordable housing [3].

Domestic affordable housing started late, and there are relatively few studies on the funding gaps and financing models of affordable housing. The research mainly focused on expanding financing channels. Lunsheng Chen and Ying Liu (2011) proposed the use of REITs for the financing of affordable housing. Yulan Tang and Yixin Xiao (2012) proposed to strengthen the leading role of local government and introduce social capital to promote the scale of financing [4]. Weisi Ma (2012) proposed to broaden financing channels, attract private capital and build loan guarantee to alleviate the financing pressure. Xuefeng Zhou (2015) believed that the PPP model could reduce the government burden and attract social capital participation [5].

To sum up, foreign researches on the new financing model of affordable housing provide many references for domestic research. The domestic scholars propose to broaden the financing channels to attract social capital, which can provide a way of thinking to solve the financing problems. However, the study biased theory is not deep enough. Therefore, it is 
necessary to make a further analysis on the actual situation in our country and put forward a new point of view.

\section{The MAIN PREDICAMENT OF CHINA'S AFFORDABLE HOUSING FINANCING}

In recent years, China has strongly supported the affordable housing construction. In the "12th Five-Year" period, the state put forward 36 million sets of affordable housing projects, basically built more than 20 million sets. And the national coverage of affordable housing reached 20\%. In 2013, Premier Keqiang Li proposed a five-year plan to renovate 10 million shantytowns. By the end of 2016, 6 million shantytowns had been reconstructed and 6 million sets were planned for 2017 . As the construction of affordable housing has increased, the government spending on construction of affordable housing has increased from 349.1 billion in 2011 to 668.2 billion in 2016. (Fig. 1) In the "12th Five-Year" period, the central government allocated 929.2 billion Yuan in subsidies for affordable housing projects. A total of 209.3 billion Yuan and 224.3 billion Yuan of subsidies were issued in 2016 and 2107 respectively. In addition to the government's budget and subsidies, the main source of affordable housing is the proceeds of land transfer and bank loans. According to the relevant literature, in "13th Five-Year" period, the funds demand for affordable housing will be increased by 23.13 percent from 5 trillion Yuan in the 12th five-year plan to 6.12 trillion Yuan. The government can support 30 percent, and the other 4 trillion needs to be obtained through other means. In this situation, the guarantee housing has achieved certain achievements. However, the financing of affordable housing still has many problems.

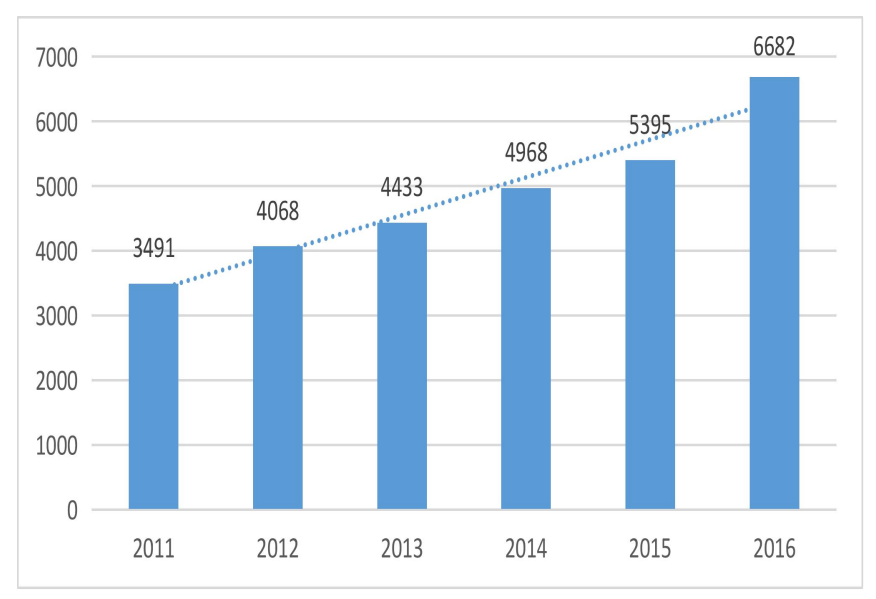

Fig.1. National financial housing security expenditure (billion Yuan)

\section{A. Excessive reliance on government financial support}

The affordable housing, which has the nature of the quasipublic products and the characteristics of public welfare, must be developed and built by the government and rely on the government to provide financial support. The main funding of affordable housing comes from government financial allocation, net income from land transfer, net profit of accumulation fund, bank loan, etc. [6]. Its financing channels are scarce and its form is simple. In the face of 6.12 trillion affordable housing fund needs in the "13th Five-Year" period, it can only rely excessively on the government funds supports to cause the government financial pressure too much. Therefore, actively exploring financing channels and enriching financing methods can fundamentally solve the financing problems faced by China's affordable housing.

\section{B. Low social capital investment}

In the "12th Five-Year" period, 36 million housing units planned to be built are estimated to be about $37 \%$ of the government's investment, with bank loans and businesses raising about $45 \%$, which indicates that the investment in social capital is severely inadequate. The holders of social capital will consider whether to invest in the project based on the rate of return of the project. First of all, the characteristics of the public welfare of affordable housing make its profits extremely low. Affordable housing costs less than commercial housing and the government says it can only get a $3 \%$ profit margin. The rents of low-rent and public housing are very low. Besides, they require the government to subsidize them properly. In fact, the main investment return of investors comes from the income from the sale and rental of affordable housing, which shows that the capital recovery model is single and the interest rate is too low, so social capital is reluctant to invest in affordable housing. Second, affordable housing prices change with changes in market prices and national policies, which make extremely low profits harder to estimate, and the return rate of the investor can't be guaranteed. In the end, the fund use cycle of the affordable housing construction is longer, and the application procedures of the affordable housing is more complicated, which lead to the capital to go back slowly.

\section{High financing risk}

The public welfare and low income of affordable housing, as well as the large capital scale and the long use time of capital; cause the investment subject to bear extremely high financing risks. However, the lack of guarantee mechanism of affordable housing financing in China is one of the main reasons for high financing risk. In 2010 our country issued the "Notice of the State Council on Strengthening Management of Local Government Financing Platform Companies", pointing out that local governments at all levels shall not provide security for the financing activities of financing platform companies in the form of state-owned assets such as fiscal revenue, administration and other units or any other direct and indirect forms. On the other hand, the lack of guarantee mechanism makes the development of new financing models such as PPP and REITS slow, resulting in a single financing mode and lack of diversified financing subject. So the financing risk can't be effectively shared.

\section{The Main Suggestions to Break Through the DILEMMA OF CHINA'S AFFORDABLE HOUSING FINANCING}

\section{A. Improve the role and functions of government}

Affordable housing is dominated by the government, and over-reliance on government can bring huge fiscal pressure on the government. Therefore, the government needs to make appropriate changes in its role and give full play to its functions. First, the government should be transformed from the primary suppliers of affordable housing funds and the manager to the facilitator, the cooperator and the supervisor. Namely, the government actively strengthens the cooperation with private 
enterprises and other social capital, and introduces innovative financing modes such as PPP and REITs to play the market role. Then, to fully exercise its functions, it is necessary to clarify the responsibilities of the central and local governments, which are mainly reflected in their respective for affordable housing fund support, land allocation, supervision and administration, and the formulation of relevant policies for financial institutions.

\section{B. Actively explore the financing models}

a) According to the actual situation of our country, it is necessary to explore the appropriate PPP mode for affordable housing:PPP is a model of mutual cooperation, benefit sharing and risk sharing between government and private enterprises [7]. The government should adopt different PPP operation models according to different types and characteristics of affordable housing (Fig. 2):Affordable housing with stable income through market operation adopt BTO model, that is, the government buys back the affordable housing after the construction of enterprise financing, but the enterprise is responsible for the operation and management of the affordable housing including maintenance and property management. For low-rent housing and public rental housing, the new parts can take the BOT model, that is, the enterprise is responsible for the financing and construction of the guarantee room, operate and manage it within the concession period, and transfer it to the government according to the agreement after the expiration; and the others such as government-purchased houses can take the ROT model, that is, the enterprise is responsible for the financing and reconstruction of housing, operate and manage it within the concession period, and transfer it to the government according to the agreement after the expiration. For shantytowns reconstruction housing, the new parts can take BTO financing model.

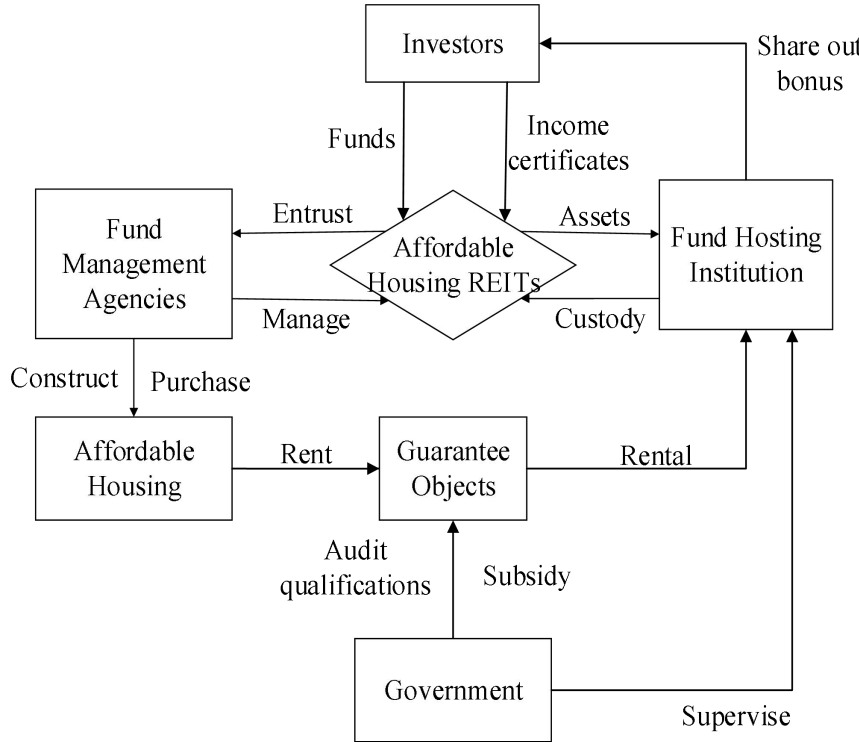

Fig.2. The general operation form and mode selection of the PPP project in the affordable housing

b) The introduction of REITs used in low-cost housing and public rental housing:REITs is a kind of trust fund that is raised funds by issuing income certificates, conducts real estate investment and management by specialized investment institutions and distributes the comprehensive income to investors according to the proportion[8]. China's affordable housing and shantytowns reconstruction housing can be sold through the market and capital recovery is relatively rapid, so the financing pressure is relatively small. For low-rent housing and public rental housing, their only non-operating mode of rent and sale, a long time to return on capital, lower rental income characteristics make their financing more pressure. Therefore, the government may choose to apply the REITs model mainly to low-rent housing and public rental housing. First of all, the sponsor of the project set up a REITs for affordable housing. The sponsor of the project can be a stateowned real estate development enterprise, a state-owned trust company, etc. Then the fund management institutions with higher credit rating are entrusted to manage REITs of affordable housing and issue income certificates to raise funds. In order to ensure the safety of funds, the fund custodian institutions such as policy-based banks hold the fund assets and are responsible for the settlement and information monitoring of fund assets. Finally, the fund management agencies invest fund assets in the construction and acquisition of affordable housing, the housings are rented out to the insured person through the government qualification examination, and the fund custodian collect the rent and dividends the pays to the investors according to the income voucher. Among them, the government, in addition to qualification examination, provides a certain subsidy and supervision of the fund trusteeship. (Fig. 3)

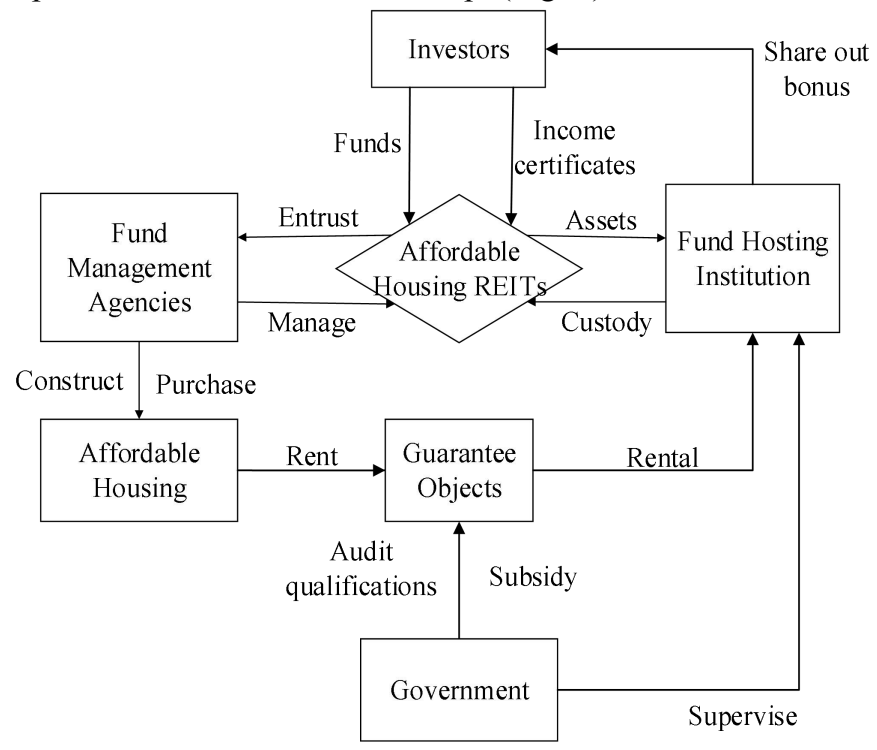

Fig.3. The REITs operation mode of the guarantee room

\section{Rich way to return the money}

In order to attract social capital to participate in the construction of affordable housing, it will increase the rate of return of investors by enriching the return on capital and use matching investment as a way of increasing the return on capital. The matching investment refers that the government provides the development of the affordable surrounding area and the property management of affordable housing and other 
business for investors to develop, so that the investors can get the benefit from them. The government provides the property management of the affordable housing to investors. Then the investors manage the property and obtain the corresponding property income from it. The government provides subsidized housing decoration projects to investors, with the market price charged, adding additional decorative income. At the same time, the government can take commercial and infrastructure facilities around affordable housing for investors to develop so that investors can increase their income.

\section{Prefect the risk guarantee mechanism}

First, the government sets up special guarantee fund for affordable housing financing. The fund comes mainly from the land transfer fee of $1 \%$ of the total, and the rest of the source of businesses or individuals. The fund earmarked specifically for affordable housing financing and guaranteed the loan provided by the purchase affordable housing of the object, reducing bank loans and investor risk. Second, the implementation of thirdparty management ensure affordable housing finance funds for "isolation." the government entrusts the specialized asset management agencies or financial institutions such as banks to manage the housing fund and sets up an independent account for the funds by a third party company to supervision and control of capital operation and timely feedback of information to investors. Thirdly, in view of the innovative financing model such as PPP model and REITs model, the minimum income guarantee mechanism is designed according to the actual conditions of the development of affordable housing in China based on the principle of minimum return on investment. The government then takes the non-performance guarantee, performance guarantee and reward mechanism according to performance appraisal.

\section{CONCLUSIONS}

Through a comprehensive analysis of the three concrete manifestations of the dilemma of affordable housing financing in our country, including over-reliance on government, low social capital participation and high financing risk, combined with the livelihood project positioning and public welfare characteristics of affordable housing, this paper puts forward some countermeasures to solve the financing dilemma of affordable housing. The construction of affordable housing requires the government to lead, but the government should change its role and gives full play to its functions. The construction of affordable housing needs to actively explore the new financing model and attract the participation of social capital. At the same time, enrich the way of capital return and improve the risk guarantee mechanism and thus enhance the enthusiasm of social capital participation through the two-way measures of income promotion and risk reduction. At present, this paper is still in the theoretical exploration stage, and needs to be deepened and refined according to practical demands.

\section{ACKNOWLEDGMENT}

The author acknowledges the financial support from the National Social Science Foundation of China (Grant No.15ZDC022; Grant No.17BGL209) and National Natural Science Foundation of China (Grant No.71373199).

\section{REFERENCES}

[1] Julie Lawson, Vivienne Milligan, "International trends in housing and policy responses, " AHURI Final Report, 2007,pp. 68-79.

[2] Milligan V, Gilmour T., "Affordable housing strategies," International Encyclopedia of Housing \& Home, 2012, pp. 58-64.

[3] Razak D. A., Mohammed M. O., Tarique K. M., “Abandoned Housing Projects in Malaysia and the Prospect of DP: An Overview," Procedia Economics \& Finance, 2015, vol. 31, pp. 813-822.

[4] Yulan Tang, Yixin Xiao, "Research on the financing strategy of China's affordable housing," Economic Review, 2012, pp. 37-40.(In Chinese)

[5] Xuefeng Zhou, "Research on the PPP financing model of barrier housing -- Taking Henan as an example," Construction Economics, 2015, vol. 36 , pp. 91-94.(In Chinese)

[6] Heng Xie, Wenjun Zhou, "The financing mode of foreign guarantee housing construction for reference," Macroeconomic Management, 2012 pp. 89-91.(In Chinese)

[7] Qilong Wang, "A Review of Researches on Social Housing Financing in China," Southwest Finance, 2016, pp.36-42.(In Chinese)

[8] Jiahua Wang, Rui Xu, Luyao Liu, Jie Zhang, "Innovative Research on Financing Modes of Safeguard Housing Construction," Communication of Finance and Accounting, 2016, pp.11-12.(In Chinese) 